\title{
Cartilage Regeneration Using a Fibrin and Autologous Cultured Chondrocytes Mixture in a Canine Model
}

\author{
Chang-Kwon Ko', Eun-Young Lee ${ }^{1}$, Jae-Deog Jang ${ }^{1}$, Seok-Jung Kim², Dong-Sam Suh ${ }^{1}$ and Cheong-Ho Chang ${ }^{1 *}$
}

${ }^{1}$ Sewon-Cellontech Co. Ltd., Seoul, Korea

${ }^{2}$ Catholic University of Korea, College of Medicine, Seoul, Korea

\begin{abstract}
Background: Various surgical methods have been designed to avoid the necessity of using periosteum, i.e. an operative weak point of autologous chondrocyte implantation $(\mathrm{ACl})$ which is a representative method for treating articular cartilage injury. This study was performed in the attempt to develop a simple, injectable type of $\mathrm{ACl}$ to in order facilitate the surgical process.

Methods: Seven of 10 dogs were used for the injectable type $\mathrm{ACl}$ using fibrin, while the remaining three dogs were used for implantation according to the previous surgical method using periosteum. The left knee of each dog was incised in order to expose the medial femoral condyle, and a circular defect was then made to $5 \mathrm{~mm}$ in diameter on the articular cartilage of the exposed medial femoral condyle so that chondrocyte implantation using periosteum and the injectable chondrocyte implantation using fibrin glue could both be performed. At week 12 following surgery, the cartilage was observed and compared histologically with normal articular cartilage.

Results: The surface of the cartilage newly generated at week 12 was very smooth and even, and it was also seen that the entire area was completely regenerated. Through the histological evaluation, IHC test, and electron microscope pictures, it was verified that collagen type II was normally expressed and that the ultrastructure of the regenerated tissue showed the normal cartilage properties.
\end{abstract}

Conclusion: Gel-type $\mathrm{ACl}$ using fibrinfor articular cartilage defects of the knee, appears to be an effective method for the regeneration and growth of cartilage and also has many potential surgical advantages.

Keywords: Autologous chondrocyte implantation (ACI); Fibrin glue; Gel-type ACI; Regenerated cartilage tissue

\section{Introduction}

As articular cartilage has only limited ability to regenerate [1], there are many treatment options for cartilage injuries, such as arthroscopic debridement, microfracture, drilling, osteochondral transplantation, and autologous chondrocyte implantation (ACI). Among these treatments, autologous chondrocyte implantation (ACI) has become the standard technique used for the repair of symptomatic, fullthickness, chondralinjuries [2-4].

However, this technique, when using liquid-type chondrocytes, is not optimal as it uses the periosteum [5] to cover the defect so that it is watertight.Therefore, the surgical exposure should be large enough to securely suture the periosteum to the defect. There is also a high risk for breakdown of the periosteal graft and subsequent progression to arthritis. To solve the periosteum-associated problem, collagen membrane is being used rather than autologous periosteum in order to avoid the necessity of a second incision for harvesting tibialperiosteum and of suturing the periosteum to the cartilage in the water-tight mode in order to shorten the surgery. Even though that technique is preferable to conventional ACI in that it is a simple method and does not use periosteum, there are some potential drawbacks with respect to cell loss and detachment of the membrane. Subsequently, the necessity for developing a new method is continually increasing.

If we use an injectable carrier, these problems can be overcome. Fibrin sealants are biological adhesives that mimic the final step of the coagulation cascade. They are used to reduce both blood loss and postoperative bleeding [6].Our study involved an evaluation of the effectiveness of injectable ACI (gel-type ACI) using fibrin glue.

\section{Materials and Methods}

\section{Experimental animals}

Ten male beagle dogs, each weighing approximately $25 \mathrm{Kg}$, were kept for one week prior to the experiments. All animals were maintained under identical conditions. The Institutional Review Board of our institution approved this study protocol. This experiment was performed in accordance with the ILAR (Institute of Laboratory Animal Resources) Guide for the Care and Use of Laboratory Animals.

\section{Autologous articular cartilage harvest for culture}

$50 \mathrm{mg}$ of cartilage from a non-weight-bearing portion of the medial femoral condyle, was collected. The piece of cartilage was simply washed with HBSS ((Hank's balanced salt solution, lonza Ltd. Muenchensteinerstrasse, Switzerland) containing antibiotics and was then chopped into $1 \sim 2 \mathrm{~mm}^{3}$ slices in order to isolate only the chondrocytes. The chondrocytes were then cultured by adding

*Corresponding authors: Cheong-Ho Chang, Sewon-Cellontech Co. Ltd 801 Wooyoung Techno Center, 273-15 Seongsu 2-ga 3-dong, Seongdong-gu, Seoul 133-831, Korea, Tel: +82.2-460-3280; Fax : +82.2-460-9725; E-mail: chc@swcell.com

Dong-Sam Suh, PhD, Sewon-Cellontech Co. Ltd., 801 Wooyoung Techno Center, 273-15 Seongsu 2-ga 3-dong, Seongdong-gu, Seoul 133-831, Korea, Tel: +82.2-460-3280; Fax : +82.2-460-9725; E-mail: dongsam@swcell.com

Received May 11, 2012; Accepted July 26, 2012; Published July 28, 2012

Citation: Ko CK, Lee EY, Jang JD, Kim SJ, Suh DS, et al. (2012) Cartilage Regeneration Using a Fibrin and Autologous Cultured Chondrocytes Mixture in a Canine Model. J Tissue Sci Eng 3:114. doi:10.4172/2157-7552.1000114

Copyright: (c) 2012 Ko CK, et al. This is an open-access article distributed under the terms of the Creative Commons Attribution License, which permits unrestricted use, distribution, and reproduction in any medium, provided the original author and source are credited. 
DMEM(Dulbecco's Modified Eagle's Medium, Gibco BRL, Rockville, MD, USA) medium containing 10\% FBS (Fetal Bovine Serum,Trace Biosciences, Nobel Park, Victoria, Australia). The increased number of chondrocytes was treated with trypsin (Gibco BRL, Rockville, MD, USA) in order to harvest the cells [7,8].

\section{Surgical procedure}

Autologous chondrocyte implantation was performed when $15 \times 10^{6}$ chondrocytes had been cultured for three weeks after the initial surgery. The dogs were anesthetized with ketamine and were placed in a supine position. A longitudinal, midline skin incision was made and extended $6 \mathrm{~cm}$ above the superior pole of the patella to the level of the tibia tubercle. Subcutaneous tissue was divided in the line of the skin incision. A medial skin flap was made to expose the quadriceps tendon, the medial border of the patella, and the medial border of the patellar tendon. A medial, parapatellar, capsular incision was then made, and the patella was dislocated laterally in order to expose the femoral condyle.

Defect making:A defect was formed up to the subchondral bone by making a lesion $5 \mathrm{~mm}$ in diameter and $5 \mathrm{~mm}$ deep. A hole for enhancing the adhesive force of injected fibrin was then made at the center of the lesion to a width of $1.5 \mathrm{~mm}$ in diameter and $2 \mathrm{~mm}$ deep in order to be able to inject fibrin into it so as to generate an anchoring point (Figure 1A).

Autologous chondrocyte implantation using periosteum: A second incision was then made over the medial subcutaneous border of the tibia just distal to the pesanserinus insertion, and a periosteal flap was then harvested while taking care not to damage or perforate the graft; the flap was then sutured in place (cambium layer down) over the defect using 5-0 or 6-0 Vicryl sutures (Ethicon Incorporated, New Brunswick, NJ, USA), while leaving a small, unsutured region to allow injection of the expanded chondrocytes. Testing to confirm a watertight seal was performed using instilled saline, and the sutured edges were sealed as needed with autologous fibrin glue. Chondrocytes were implanted using a 23-gauge angiocatheter, after which the remaining open edge of the periosteal flap was secured with several sutures and was then sealed (Figure1B).

Autologous chondrocyte implantation using fibrin: For the injection procedure, two, $1 \mathrm{ml}$ syringes and a Y-shaped mixing catheter were used. In one syringe, $1 \mathrm{ml}$ of fibrinogen (Green Plast, Green Cross Inc., Korea) was filled with medium, and the other syringe was filled with $0.9 \mathrm{ml}$ of cell suspension $\left(15 \times 10^{6}\right.$ chondrocytes $)$ and $0.1 \mathrm{ml}$ of thrombin (50 IU). Cultured autologous chondrocytes mixed with fibrin (1:1) were then slowly injected into the defect area.

In order not to overflow the margin, the dependent position of the defect site was maintained for five minutes. Flexion and extension motion of the knee was performed three to five times in order to check for any graft failure. The wound was then closed layer by layer [9-12] (Figure1C).

\section{Examination Methods}

\section{Gross appearance}

Twelve weeks postoperatively, all dogs from both groups were sacrificed, and areas of cartilage defect as well as portions of normal tissue were extracted. The gross appearance of the newly generated cartilage was evaluated by comparing it with normal tissue[11,13,14]. A total of four items, i.e. surface coverage, lesion color, smoothness of the surface of the cartilage, and thickness of the regenerated cartilage, were observed, and all cartilage of the surgically treated area was evaluated regarding the items by assigning each item from 0 to 13 points and by measuring down to the first decimal place depending on the grades. First, the surface coverage of the total area of a lesion was divided into five grades to give $4,3,2$ or 1 point to the lesion area greater than $75 \%$, $50 \sim 75 \%, 25 \sim 50 \%$, and under $25 \%$, respectively, and no point was given to no generation of the lesion.Next, lesion color which is a key criterion of the constituents and maturity of regenerated cartilage, was divided into a total of three grades, giving 4 points if the color was the same as that of normal tissue, 2 points if it was yellow or reduced (a little of transmittance), and 0 points if it was very different from normal cartilage or substantially reduced in transmittance.Third, the smoothness of the surface of the cartilage was assessed and divided into 4 grades, giving 3 points if the surface was smooth, 2 points if it was irregularly smooth, 1 point if the surface showed any cleft or depression, and no points if the surface of the cartilage sank as far as the tidemark.Lastly, the thickness of the regenerated cartilage was investigated and divided into 3 grades. Two points were given if the thickness was at the same level as that of the normal cartilage, 1 point if it was greater than $50 \%$, and no points if it was less than $50 \%[13,15,16]$.

\section{Histochemical staining}

Regenerated cartilage and normal cartilage were extracted from each experimental animal that had been injected with cultured chondrocyte and fibrin and fixed by $3.7 \%$ neutral buffered formalin (Sigma, Poole, UK).The cartilage was then immersed and decalcified in the decalcifying solution diluted with formic acid :nitric acid : $\mathrm{H}_{2} \mathrm{O}=$ 25:5:70. After decalcification, the cartilage was dipped and neutralized in $5 \%$ sodium sulfite solution (Sigma, Poole, UK) and then rinsed with water. It was then immersed for one hour in each of 50, 60, 70, 80,90 , and $95 \%$ ethanol solutions, and absolute ethanol so as to be gradually dehydrated.After dehydration, the cartilage was immersed in xylen(Duksan, Korea)and was infiltrated with paraffin so it could be cut into blocks.Sections were cut from the block using a microtome (Leica,Wetzlar, Germany) in order to perform histochemical staining. Each section was then stained with hematoxylin and eosin to in order to observe the tissue morphology and with Alcian blue and Masson's trichrom so as to check the collagen of the cartilage as well as the GAG content[17].

\section{Immunohistochemistry}

Immunohistochemistry was performed on the same serial sections as those used in the histochemical staining.Antibodies used in the immunohistochemistry were IH11 for collagen type I (abcam, Cambridge Science Park, UK) and CIIC1 for collagen type II (abcam, Cambridge Science Park, UK).IH11 and CIIC1 were separately cultured at $10 \%$ DMEM, and the culture media were centrifugally separated. Dot blot analysis was then performed to determine the concentration of an approximate antibody by titration so it could be used as the primary

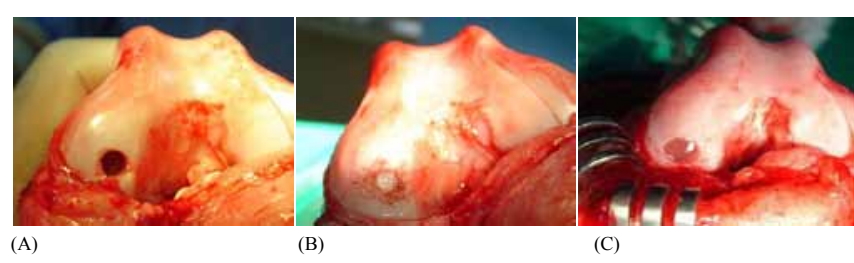

Figure 1: Photographs before and after $\mathrm{ACl}$. (A) A round hole with a diameter of $5 \mathrm{~mm}$ and a depth of $5 \mathrm{~mm}$ was made in the lateral femoral condyle. (B) Conventional $\mathrm{ACl}$ using periosteum. (C) Gel-type $\mathrm{ACl}$ using fibrin. 
antibody.A universal antibody of the elite $\mathrm{ABC}$ kit (Vector, Burlingame, UK) was used as a secondary antibody to induce a secondary antibody reaction, and the DAB reagent (Vector,Burlingame, UK) was used to generate the color reaction [18].

\section{Electron microscopy}

A transmission electron microscope was used to observe the ultrastructure of the regenerated cartilage generated in each experimental animal which had been injected with fibrin and chondrocyte.The regenerated cartilage was washed with DPBS(Dulbecco's PhosphateBuffered Saline, Gibco, Gaithersburg, MD, USA), was then fixed using a universal fixative (formaldehyde/glutaradehyde) and post-fixed using osmium tetroxide (Sigma, Poole, UK), and was finally embedded in resin. The serial sections were mounted on oval, 2-mm, one-hole grids and were stained with uranyl acetate and lead citrate in order to be able to perform electron microscopy (Leica,Wetzlar, Germany) [19-21].

\section{Molecular Biological and Biochemical Analyses}

\section{Relative quantification of real-time RT-PCR}

Real-time RT-PCR was performed to compare the relative quantities of gene expression so as to identify the gene expression pattern of the newly generated cartilage. The relative expression patterns of collagen type II (primer Can-C2A1 F, R), a main component of the cartilage, and aggrecan (primer Can-AGG F, R), a component of GAG, were analyzed using a non-inducible gene GAPDH (primer Can-GAPDH $F, R$ ) of the normal cartilage as the reference standard. Relative gene expressions of the regenerated cartilage were analyzed to investigate the features of the regenerated cartilage at the gene level $[8,22]$.

The normal cartilage and the regenerated cartilage were collected and added to $\mathrm{LN}_{2}$ so they could be ground down. RNA was then separated using trizol reagent (invitrogen, Gaithersburg, MD,USA) and was quantified by measuring its absorbance at $260 / 280 \mathrm{~nm}$.RTPCR was performed using a LightCycler (LC-1288, Roche, Mannheim, Germany) in order to relatively quantify the genes, and SYBR Green I (Roche, Mannheim, Germany) was used as a detection dye for realtime quantification detectable in the analysis using LCS4 software (Roche, Mannheim, Germany).

The primers used in RT-PCR are shown in Table 1.
Synthesis of cDNA used RNA separated from each piece of cartilage, AMV reverse transcriptase (Roche, Mannheim, Germany), and oligo$\mathrm{dT}$ as a primer. The conditions of the PCR reaction using the above cDNA as a template, are shown in Table 2. Agarose gel electrophoresis $(10 \%$ agarose, $100 \mathrm{~V}, 30 \mathrm{~min}$ ) was also performed to determine whether the RT-PCR products were generated through a normal reaction or a non-specific reaction.

\section{Collagen analysis}

SDS-PAGE analysis: Cartilage tissue was separated from the normal cartilage (NC), post-cartilage (PC), and surface cartilage (SC) of the newly generated cartilage, and collagens were separated from the tissue using a well-known pepsin digestion method.140mg, $80 \mathrm{mg}$, and 90mg of the normal cartilage and PC and SC of the regenerated cartilage, respectively, were added to $\mathrm{LN}_{2}$ and were ground down to powder. The powders were immersed separately into the extraction buffer (4M Guanidin- $\mathrm{HCl}, 0.05 \mathrm{M}$ Tris- $\mathrm{HCl}, \mathrm{pH} 7.5$ ) for $24 \mathrm{hr}$. The GAG and supernatant were then removed, after which a $0.5 \%$ pepsin solution $(0.5 \mathrm{M}$ acetic acid, $0.2 \mathrm{M} \mathrm{NaCl})$ was added at 20 times the volume of each pellet and was then set in reaction for $48 \mathrm{hr}$.After centrifugal separation, each supernatant was transferred into a new tube and $5 \mathrm{M} \mathrm{NaCl}$ was added to produce the final concentration $(0.8 \mathrm{M})$ which was then kept for $12 \mathrm{hr}$ in order to settle the collagen. After centrifugal separation, the supernatant was removed and the pellets were dissolved in $0.1 \mathrm{M}$ acetic acid. Salt was removed through dialysis.Collagens were quantified using a sircol assay kit (Biocolor Ltd, Antrim, UK), and 500ng of each separated collagen was loaded into the kit.SDS-PAGE (7.5\%) and staining(silver staining kit, Biorad, Hercules, CA, USA)were performed to distinguish the types of collagen $[16,23]$.

Western blot analysis: SDS-PAGE (Sodium Dodecyl Sulfate Polyacrylamide Gel Electrophoresis, Biorad, Hercules, USA)was performed to type the collagens, and electro-transfer onto PVDF (polyvinylideneDifluoride, Biorad, Hercules, USA)membrane (Amersham) was made under $200 \mathrm{~mA}$ for $45 \mathrm{~min}$. The membrane was blocked with TBST (Tris-buffered saline $0.1 \%$ Tween 20: 100mMTris$\mathrm{Cl}, 0.9 \% \mathrm{NaCl}, 0.1 \%$ Tween $20, \mathrm{pH} 7.5$ ) added to $3 \% \mathrm{BSA}$ (Bovine serum albumin, Sigma, Poole, UK)at $4^{\circ} \mathrm{C}$ and was washed using TBS The membrane was immersed in TBST containing a $\mathrm{T}$ (Tris-Cl Bovine Serium Tween20) primary antibody and was stirred at a slow speed for $1.5 \mathrm{hr}$ to facilitate the reaction. The membrane was washed five times

\begin{tabular}{|c|c|c|c|c|}
\hline Gene & Primer & Primer Sequence & & Size \\
\hline \multirow{2}{*}{ Aggrecan } & Can-Agg F & 5' GATTGAAGTCAGTGGAGACC 3' & $5991 \sim$ & \multirow{2}{*}{$236 \mathrm{bp}$} \\
\hline & Can-Agg R & 5' CTGACTCATCTGTCССTGAT 3' & $\sim 6226$ & \\
\hline \multirow{2}{*}{ Col I a1 } & Can-C1A1 F & 5' AACATGGAGACAGGTGAGAC 3' & 3950 & \multirow{2}{*}{$235 \mathrm{bp}$} \\
\hline & Can-C1A1 R & 5' AGTGGTAGGTGATGTTCTGG 3' & $\sim 4184$ & \\
\hline \multirow{2}{*}{ Col II a1 } & Can-C2A1 F & 5' TACTGTTCTGAAGGATGGCT 3' & 4313 & \multirow{2}{*}{$243 b p$} \\
\hline & Can-C2A1 R & 5' GTGACTGGGACTGGAAAGTA 3' & $\sim 4555$ & \\
\hline \multirow{2}{*}{ GAPDH } & Can-GAPDH F & 5' CCAGTATGATTCTACCCACG 3' & 135 & \multirow{2}{*}{$234 \mathrm{bp}$} \\
\hline & Can-GAPDH R & 5' GAAGGAGCAGAGATGATGAC 3' & $\sim 368$ & \\
\hline
\end{tabular}

Table 1: Primers and primer sequences.

\begin{tabular}{|l|l|l|l|l|}
\hline Reaction step & Temp $\left({ }^{\circ} \mathbf{C}\right)$ & Time $\mathbf{( s e c})$ & Cycles & Analysis mode \\
\hline Hot start & 95 & 60 & 1 & None \\
\hline \multirow{3}{*}{ Amplification } & 95 & 5 & \multirow{2}{*}{ Acquisition mode } & Quantification \\
\hline Melting curves & 59 & 5 & & None \\
\hline Cooling & 72 & 10 & None \\
\hline Single \\
\hline
\end{tabular}

Table 2: Reaction condition of relative quantification of RT-PCR analysis. 
with TBST and was then immersed in TBST containing a secondary antibody for $1 \mathrm{hr}$. Detection by the secondary antibody combined with enzyme used an ECL (enhanced chemiluminescence) kit (Amershampharmacia Biotech, Sweden) and was exposed onto X-ray film (Amersham Pharmacia Biotech, Sweden) and then developed. Anti-collagen type I antibody (monoclonal, mouse Ig G, abcam, Cambridge Science Park, UK) and anti-collagen type II antibody (monoclonal, mouse Ig G, abcam, Cambridge Science Park, UK) were used as the primary antibody.Anti-mouse $\lg \mathrm{G}$ antibody (monoclonal, Goat, Amershampharmacia Biotech, Sweden) linked with horseradish peroxidase, was used as the secondary antibody [9,24-27].

HPLC (high performance liquid chromatography) analysis: For HPLC analysis, each sample was diluted up to $0.6 \mathrm{mg} / \mathrm{ml}$ with $\mathrm{HCl}(\mathrm{pH}$ 2.0). Chromatography was analyzed at wavelength $220 \mathrm{~nm}$ using a U.V. absorbance detector(Waters 2487 dual lamda, Milford, MA, USA).

Mobile phase chromatography was moved at a flow rate of $0.5 \mathrm{ml} /$ min by $0.25 \mathrm{M} \mathrm{NaCl} / 5 \mathrm{mM}$ acetic acid [28].

\section{Results}

\section{Comparison between conventional ACI and gel-type ACI}

Gross appearance: Twelve weeks after conventional ACI and geltype ACI, both treatments allowed good cartilage regeneration. With conventional ACI, the cartilage regeneration state was very good and the thickness of the cartilage defect was completely filled with regenerated cartilage. However, the scar stitched with sutures was still apparent. On the other hand, with gel-type ACI, the surface was very uniform and the connection with normal tissue was smooth. In addition, the cartilage color was even and its quality was the same as that of normal tissue $[15,29]$. In both experiments, formation of cartilaginous tissue was confirmed and the color of the regenerated cartilage was deeper than that of normal tissue because as the depth of the defect was deeper than that of normal cartilage, the newly formed cartilage was thicker than normal cartilage (Figure2A, 2B).

Gross scoring: In both experiments, there was a total appraisal of tissue of the conventional ACI group as well as that of the gel-type ACI group. For cartilage appraisal, surface coverage of the defect was investigated and the cartilage color and surface smoothness were verified. The thickness of the regenerated cartilage was also investigated (Table 3). In the conventional ACI group, the coverage, color, and surface smoothness were 3.3 (Max. 4.0), 3.3 (Max. 4.0), and 2.3 (Max. 3.0), respectively. The thickness of the regenerated cartilage was 1.7 (Max. 2.0). On the other hand, in the gel-type ACI, the surface area coverage was 3.5 (Max. 4.0) which was slightly higher than that of conventional ACI and the cartilage color was 3.4 which was 0.1 higher than that of conventional ACI. The surface smoothness and thickness were 2.4 and 1.8, respectively, each of which was 0.1 higher than their counterparts in conventional ACI. The histological scores were computed, and the normal tissue had a score of 13. The histological scores for conventional ACI and gel-type ACI were 10.7 and 11.2, respectively, with the latter scoring 0.5 units more than conventional ACI. In general, equal or better results were displayed with gel-type ACI than with conventional ACI in all areas of the gross scoring (Table $3)$.

\section{Histological observations}

For histological observation of normal cartilage and regenerated cartilage made by transplanting the cell-gel mixture, histochemical staining was enhanced in order to compare the component composition.
Moreover, immuno-histochemical staining was performed in order to verify collagen type II which is the most important component of cartilage. Formation of chondron which is composed of chondrocyte and structures of territorial and interterritorialmatrices, was also compared using a transmission electron microscope.

Histochemical staining: Histochemical staining of regenerated cartilage made by gel-type ACI was conducted and compared with that of normal tissue. In Figure 3, the A side is newly formed cartilage created by gel-type ACI while the $\mathrm{C}$ region is intact cartilage. Region $\mathrm{B}$ shows the cartilage unity formation created by the fusion of normal cartilage and newly formed cartilage. The $\mathrm{B}$ region shows the cell array of the typical column type of cartilage. In A, the cell density of the newly formed cartilage was high, but the column type was not formed. Moreover, single cell and groups of cells that formed chondron and collagen, were very well expressed. Figure 4 is the magnified picture of the black rectangle region B in Figure 3. A direct connection was observed between the regenerated cartilage and the intact cartilage, and there was no gap or intervening tissue.

Immuno-histochemical staining: Immuno-histochemical staining (IHC) of tissue collected 12 weeks after application of 3-dimensional

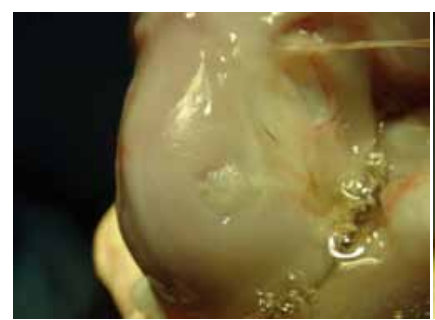

(A)

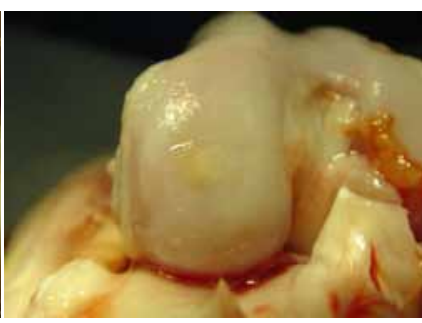

(B)
Figure 2: Gross Appearance of regenerative cartilage 12 weeks after implantation in the lateral femoral condyle. (A) ACl using periosteum. (B) Gel type $\mathrm{ACl}$

\begin{tabular}{|c|c|c|c|c|c|c|c|c|c|c|}
\hline \multirow{2}{*}{ Cartilage Evaluation } & \multirow{2}{*}{ Grade } & \multicolumn{4}{|c|}{ Normal ACT } & \multicolumn{5}{|c|}{ Gel type $\mathrm{ACl}$} \\
\hline & & \#1 & \#2 & \#3 & Average & $\# 1$ & \#2 & \#3 & $\# 4$ & Average \\
\hline \multicolumn{11}{|l|}{ I. Extent of coverage } \\
\hline$>75 \%$ surface area & 4 & \multirow{5}{*}{3} & \multirow{5}{*}{4} & \multirow{5}{*}{3} & \multirow{5}{*}{3.3} & \multirow{5}{*}{4} & \multirow{5}{*}{3} & \multirow{5}{*}{3} & \multirow{5}{*}{4} & \multirow{5}{*}{3.5} \\
\hline $50-75 \%$ surface area & 3 & & & & & & & & & \\
\hline $25-50 \%$ surface area & 2 & & & & & & & & & \\
\hline$<25 \%$ surface area & 1 & & & & & & & & & \\
\hline No new cartilage & 0 & & & & & & & & & \\
\hline \multicolumn{11}{|l|}{ II. Cartilage color } \\
\hline Normal & 4 & \multirow{3}{*}{2} & \multirow{3}{*}{4} & \multirow{3}{*}{4} & \multirow{3}{*}{3.3} & \multirow{3}{*}{3.5} & \multirow{3}{*}{2.5} & \multirow{3}{*}{3.5} & \multirow{3}{*}{4} & \multirow{3}{*}{3.4} \\
\hline $\begin{array}{l}\text { Yellow/Slight loss of } \\
\text { translucency }\end{array}$ & 2 & & & & & & & & & \\
\hline $\begin{array}{l}\text { Brow/moderate loss } \\
\text { of translucency }\end{array}$ & 0 & & & & & & & & & \\
\hline \multicolumn{11}{|l|}{ III. Cartilage surface } \\
\hline Smooth & 3 & \multirow{4}{*}{2} & \multirow{4}{*}{3} & \multirow{4}{*}{2} & \multirow{4}{*}{2.3} & \multirow{4}{*}{3} & \multirow{4}{*}{2} & \multirow{4}{*}{2.5} & \multirow{4}{*}{2} & \\
\hline Irregular & 2 & & & & & & & & & 2 \\
\hline Shallow clefts & 1 & & & & & & & & & 2.4 \\
\hline Clefts to tidemark & 0 & & & & & & & & & \\
\hline IV. Regeneratedcartila & ge Thic & kne & ess & & & & & & & \\
\hline $100 \%$ of normal & 2 & & & & & & & & & \\
\hline $50-100 \%$ of normal & 1 & 2 & 2 & 1 & 1.7 & 2 & 1.5 & 2 & 1.5 & 1.8 \\
\hline$<50 \%$ of normal & 0 & & & & & & & & & \\
\hline Total Score & 13 & 9 & 13 & 10 & 10.7 & 13 & 9 & 11 & 12 & 11.2 \\
\hline
\end{tabular}


Citation: Ko CK, Lee EY, Jang JD, Kim SJ, Suh DS, et al. (2012) Cartilage Regeneration Using a Fibrin and Autologous Cultured Chondrocytes Mixture in a Canine Model. J Tissue Sci Eng 3:114. doi:10.4172/2157-7552.1000114

chondrocyte remedy, was performed using anti-collagen types I and II antibodies, and an interface was observed between the regenerated cartilage and the normal tissue. Figure 5 is the IHC result for collagen I, and Figure 6 is the IHC result for collagen II. Area A of Figure 5 and Figure 6 also represent normal tissue among the interfaces. Area $\mathrm{C}$ of Figure 5 and Figure 6 represents newly formed cartilage by gel-type $\mathrm{ACI}$, and area $\mathrm{B}$ show the transitional region between the normal tissue and the regenerated cartilage. As shown in Figure 5, collagen type I is not expressed at all in area $\mathrm{A}$, although slight expression is observed in areas $\mathrm{B}$ and $\mathrm{C}$. In addition, the expression of collagen type II is observed in Figure 6. On the other hand, as shown in Figure 5 and Figure 6, a good interconnection was observed between the normal tissue and the newly formed cartilage. The staining intensity of collagen type II was lower on the surface of both normal tissue and newly formed cartilage, and the intensity of collagen type II in the newly formed cartilage was lower than that in normal tissue [30].

Electron microscope observation: The types of cells that comprise the structure of normal cartilage tissue and that of cartilage formed by gel-type ACI, were observed using a transmission electron microscope. In the normal cartilage (Figure 7A), two chondrocytes constituted one chondron, the nucleus and micro-organs in chondrocyte were well-developed, lipid droplets seen as white-colored structures were observed, and collagen type II was clearly observed on both the territorial

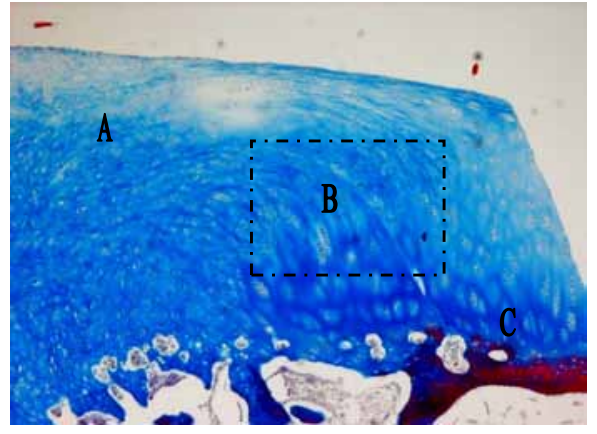

Figure 3: Photomicrograph of the section of the regenerative cartilage with the fibrin-chondrocyte mixture 12 weeks after implantation (Masson's trichorme staining for collagen. $x 40$ ). (A) Cartilage repaired with the fibrin-chondrocyte mixture shows numerous irregular groups of chondrocytes with an abundance of collagen. (B) Transitional region between the original and the regenerated cartilage. (C) Original cartilage.

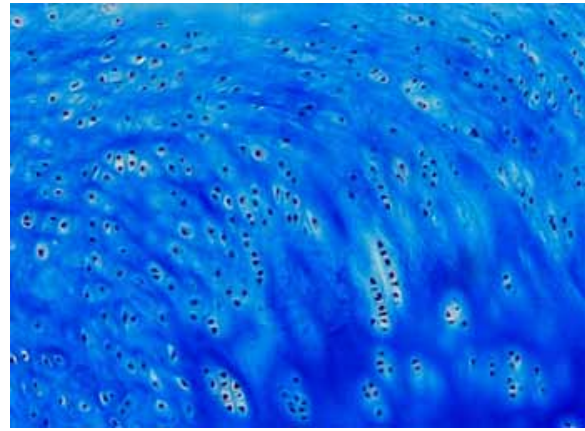

Figure 4: Magnified photomicrograph (X100) of Section B in Figure 3. Masson's trichrome staining shows a columar type of chondrocyte and has an abundant collagen matrix. Transitional region between the regenerative cartilage and the original cartilage shows good interconnection without discontinuity.

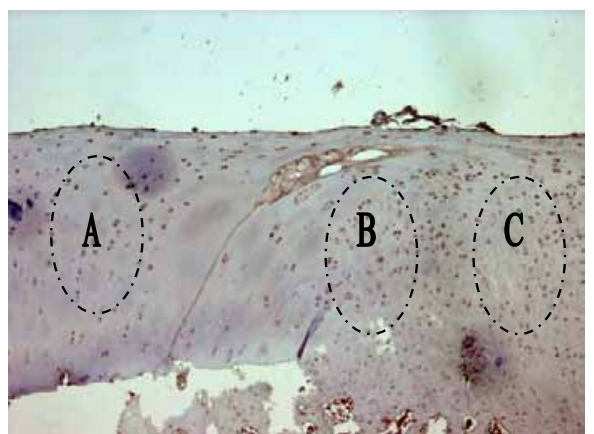

Figure 5: Photomicrograph of a section of the regenerative cartilage after immunohistochemical staining with anti-collagen type I antibody (X40).

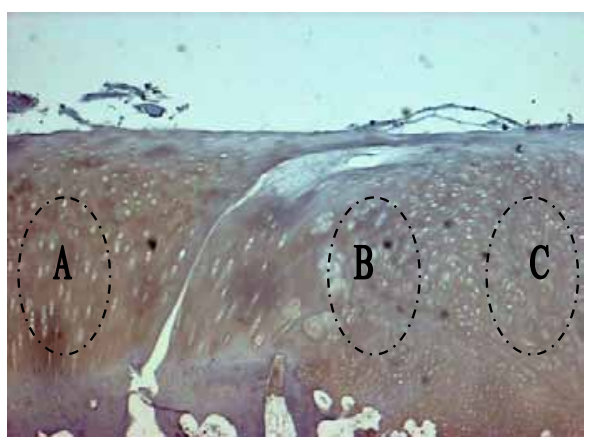

Figure 6: Photomicrograph of a section of the regenerative cartilage after immunohistochemical staining with anti-collagen type II antibody (X40).
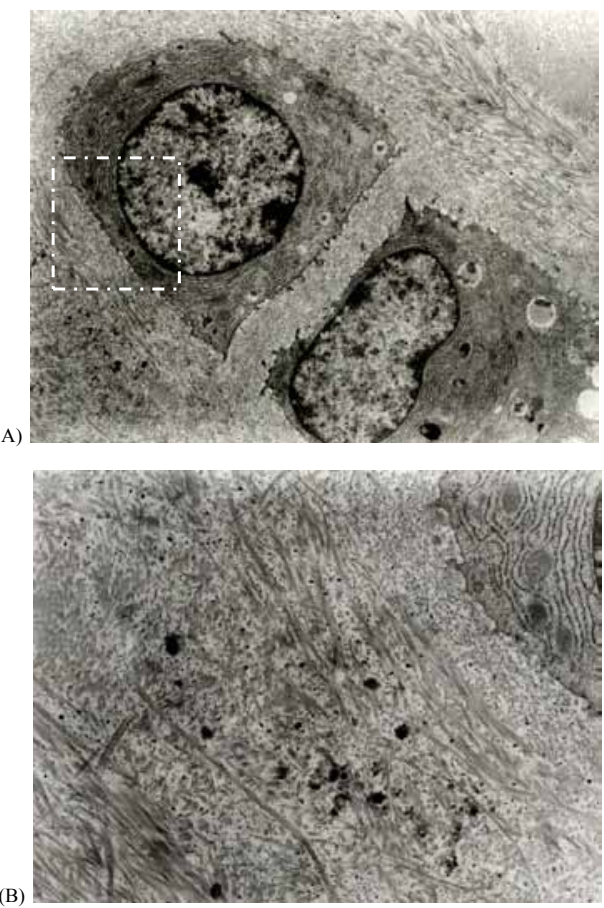

Figure 7: Photograph of electron microscope image of normal cartilage. (A) Normal cartilage with chondrocytes. 4,000X. (B) Territorial and interterritorial matrix of normal chondrocytes. 10, 000X. 
Citation: Ko CK, Lee EY, Jang JD, Kim SJ, Suh DS, et al. (2012) Cartilage Regeneration Using a Fibrin and Autologous Cultured Chondrocytes Mixture in a Canine Model. J Tissue Sci Eng 3:114. doi:10.4172/2157-7552.1000114

matrix and the interterritorial matrix surrounding the cells [31-33]. Collagen fibrils existed in various sizes, and cell processes extended from the cell membrane to the territorial matrix. In addition, Figure 7B shows magnification of the square region of Figure 7A. Collagen fibrils, composed mostly of cartilage tissue, were irregularly tangled, and striped bands were clearly observed [34]. Matrix vesicles detached from cells were also observed. A large amount of collagen surrounding cells was shown parallel to tissue segments or was observed as an oval by sectional cutting.

On the other hand, Figure $8 \mathrm{~A}$ is a transmission electron microscope picture of cartilage formed by gel-type ACI. One chondrocyte represented one chondron, nucleus, and micro organs in cells which were well-developed, such as that of normal cartilage. The territorial matrix was identified from the interterritorial matrix, and collagen fibrils were clearly observed on the matrix. Figure 8B shows a magnified square region. The process in the chondrocyte was clear, and a lipid droplet was noted which was smaller than that of normal cartilage. In addition, a number of the collagen fibrils in the regenerated cartilage made by transplanting the chondrocyte remedy, were smaller than those of normal tissue and the density was also lower. These results agree with the histologic observation that the collagen concentration of regenerated cartilage is lower than that of normal tissue [35]. Typical stripe bands were also observed in fibrils composed of collagen type II. However, in general, the density of cartilage fibril is high near the cell in an interterritorial matrix of cartilage, its density is gradually lowered, and its thickness is thus decreased. Considering these characteristics, it is reasonable to assume that active biosynthesis is advancing in the chondrocytes of cartilage formed by gel-type ACI [34], i.e., it is considered that biosynthesis of chondrocytes in normal tissue is advanced to the level of maintaining the cartilage, although chondrocytes in newly formed cartilage are still progressing toward maturation. On the electron microscope images of both normal cartilage tissue and of cartilage tissue formed by geltype ACI, chondrons composed of one or a few cells as well as the typical characteristics of cartilage tissue, were both observed as one of the results of histologic observation. Collagen type II fibril was also equally observed, however, compared to normal cartilage, the number and density of collagen fibrils in the cartilage formed by gel-type ACI, were lower, there were many processes and they were larger, and the lipid droplets were smaller. Therefore, we were able to confirm that maturation of the cartilage formed by gel-type ACI was still in process.

\section{Molecular biological and biochemical analyses}

Confirmation of real-time RT-PCR: RNA was isolated from normal tissue, surface cartilage (SC) formed on the surface of the defect, and cartilage (post-cartilage; $\mathrm{PC}$ ) formed at the anchor point made to fix the matrix; cDNA was synthesized using oligo-dTprimer, after which real time RT-PCR was performed to investigate the melting curves and melting peaks (Figure 9). As a result of this analysis, peaks were observed at $88.8^{\circ} \mathrm{C}, 87.2^{\circ} \mathrm{C}, 88.8^{\circ} \mathrm{C}$, and $86.5^{\circ} \mathrm{C}$ for $\mathrm{C} 1 \mathrm{Al}$, C2A1, AGG, and GAPDH, respectively. We were thus able to confirm that PCR was achieved normally. RT-PCR was also confirmed by electrophoresis of the final products loaded on 10\% agarose gel (Figure $10)$. On the other hand, the PCR product did not amplify from the nontemplate control (NTC-GAPDH), a negative control.

Relative quantification of real-time RT-PCR: Real time RT-PCR was performed using RNA as a template isolated from the surface cartilage (SC) and post-cartilage (PC) of both normal tissue (NC) and regenerated cartilage, after which the expression was analyzed by relative quantification $[36,37]$. Relative quantification of each gene was investigated by setting GAPDH, a housekeeping gene, as a standard. In $\mathrm{PC}$ of regenerated cartilage, gene expression was $0.0258,1.74$, and 0.0121 for C1A1, C2A1, and AGG, respectively, while in SC, it was $0.020,2.38$, and 0.0135 . In $\mathrm{NC}$ of normal tissue, gene expression was $0.0156,1.04$, and 0.0155 (Figure 11). The relative expression of PC and SC genes on NC was also compared based on the relative expression of GAPDH in each tissue. The relative gene expressions were calculated by referencing the rate of GAPDH of PC to GAPDH of NC, dividing the expression value of the $\mathrm{PC}$ genes by the expression value of the $\mathrm{NC}$ genes, and then multiplying by reference. PC/NC for C1A1, C2A1, and AGG was $1.63,1.77$, and 0.84 , respectively. $\mathrm{SC} / \mathrm{NC}$, the relative

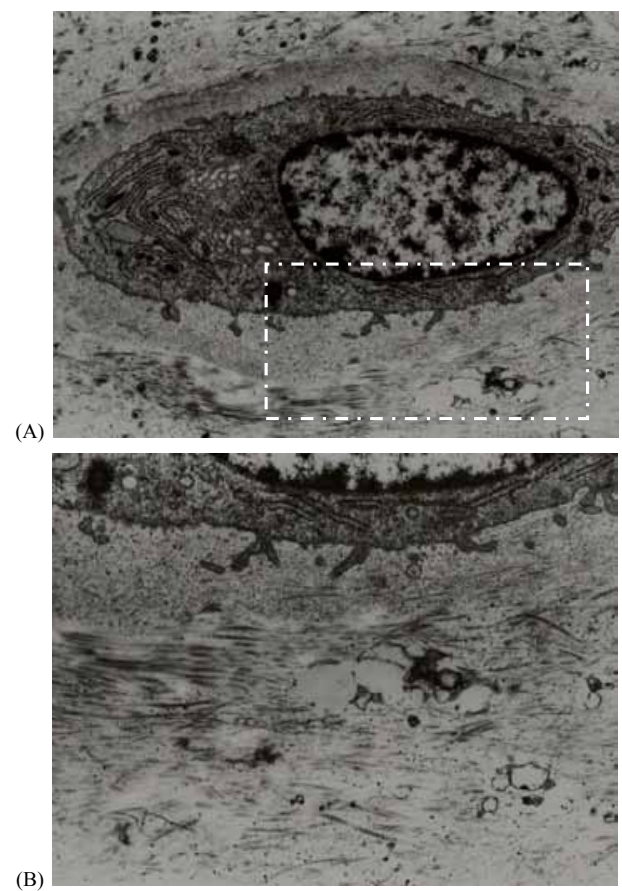

Figure 8: Photograph of electron microscope image of regenerative cartilage. (A) Chondrocyte and cell organelles in regenerated cartilage. 6,000X. (B) Territorial matrix of chondrocytes in the regenerated cartilage. 10, 000X.

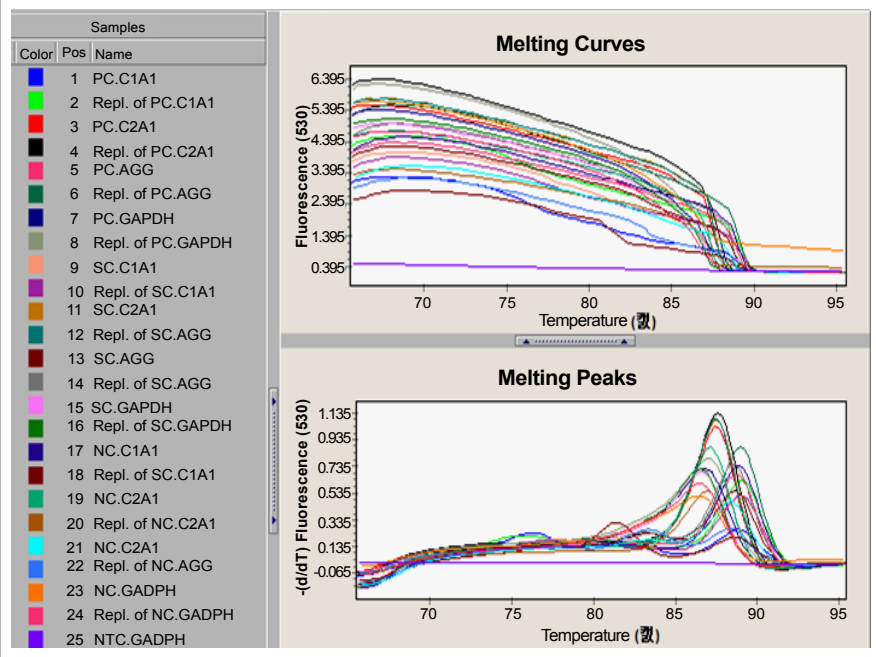

Figure 9: Analysis diagram of the condition of the melting curve and the melting peak on RT-PCR. 

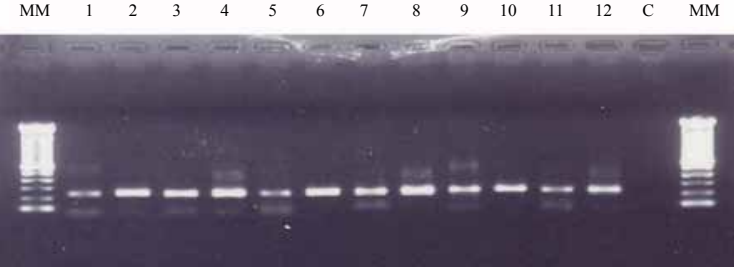

$\begin{array}{cl}\mathrm{M} / \mathrm{M} & \text { Molecular marker } \\ 3 & \text { PC-AGG } \\ 6 & \text { SC-C2A1 } \\ 9 & \text { NC-C1A1 } \\ 12 & \text { NC-GAPDH }\end{array}$

$\begin{array}{clrl}1 & \text { PC-C1A1 } & 2 & \text { PC-C2A1 } \\ 4 & \text { PC-GAPDH } & 5 & \text { SC-C1A1 } \\ 7 & \text { SC-AGG } & 8 & \text { SC-GAPDH } \\ 10 & \text { NC-C2A1 } & 11 & \text { NC-AGG } \\ \text { C } & \text { NTC-GAPDH } & & \end{array}$

*PC: regenerated cartilage of the deep-hole area made by the drill. SC: regenerated cartilage of the surface area of $\mathrm{NC}$ : normal cartilage

Figure 10: Representation of the size analysis of the end product on RT-PCR.

gene expression, was 2.77, 2.39, and 1.31 for C1A1, C2A1, and AGG, respectively. In PC compared to NC, collagen types I and II were often expressed while aggrecan expression was reduced. Also, in SC, expression of all collagen type I, type II, and aggrecan was increased (Figure 12). These results agree with those observed and estimated using an electron microscope $[38,39]$. Specifically, most cartilaginous tissue formed at 12 weeks after gel-type ACI, was composed of collagen type II, but maturation was incomplete and was still in progress. On GAPDH, a non-inducible gene in all tissues, collagen I showed a $1 \sim 2 / 100$ level, aggrecan also displayed a 1 1.5/100 level indicating very low expression or no expression, and collagen type II was expressed $1 \sim 2$ times higher. With these results, it was confirmed that regenerated cartilage displays the same genetic expression pattern as normal tissue and is composed primarily of collagen type II.

\section{Collagen Analysis}

\section{SDS-PAGE analysis}

The collagen type was identified by SDS-PAGE which was performed with collagen previously used for HPLC analysis. After SDSPAGE was performed, the collagen isolated from each tissue sample was compared to the bands of collagen type I (Col I) and collagen type II (Col II), using both as standards. Collagen isolated from each tissue was identified as type II collagen. In addition, comparison with the molecular weight marker $(\mathrm{M} / \mathrm{M})$ coincided with the size of collagen type II. These results also agree with the HPLC analysis results previously obtained (Figure 13).

\section{Western blot analysis}

After SDS-PAGE was performed with collagens isolated from cartilage tissue, western blot analysis was conducted using a monoclonal antibody to collagen type I and collagen type II $[40,41]$. Collagens isolated from normal tissue were used as the positive control, and collagen types I and II were used as the standards. In the results of Western blotting using anti-collagen type I antibody, a band was not observed in either the collagen of PC and SC isolated from regenerated cartilage or in NC. A band was only observed in the collagen type I standard. In the results of Western blotting using anti-collagen type II antibody, bands were also observed in NC which served as the positive control in the collagen type II standard as well as in PC and SC (Figure $14)$.

\section{HPLC analysis}

Quantification was performed using collagen (NC) isolated from normal cartilage, collagen isolated from pillars of regenerated cartilage (post-cartilage collagen; PC) formed by gel-type ACI, and collagen from

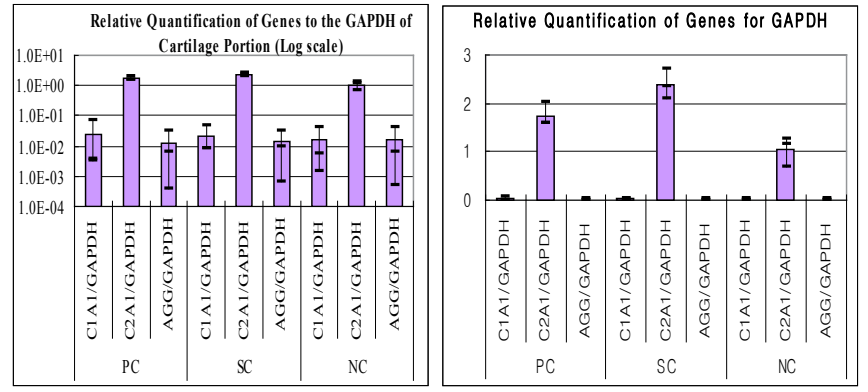

*PC: regenerated cartilage of the deep-hole area made by the drill. SC: regenerated cartilage of the surface area of NC: normal cartilage

Figure 11: Comparison of the relative quantification of the end-product genes of RT-PCR with the GAPDH genes regarding collagen types I and II. Graph of the relative quantification analysis of the end-product genes compared to GAPDH genes (left) and the log graph of it (right).

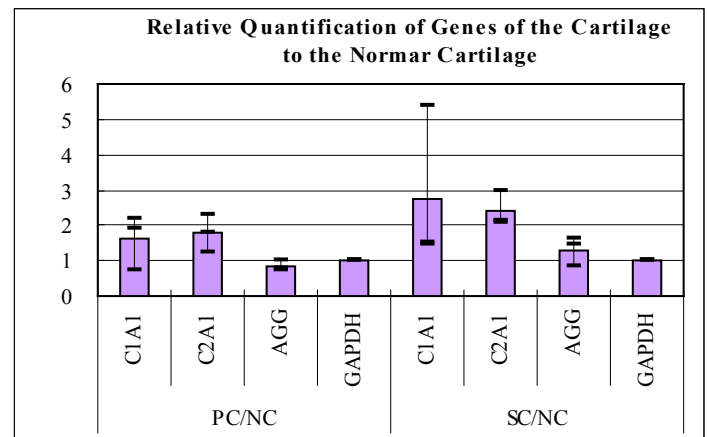

*PC: regenerated cartilage of the deep-hole area made by the drill. SC regenerated cartilage of the surface area of NC: normal cartilage

Figure 12: Comparison of the relative quantification of the end-product genes regarding aggrecan, Collagen type I and II which was harvested from regenerated cartilage (PC, SC) of RT-PCR compare to normal cartilage's collagen type I and II.

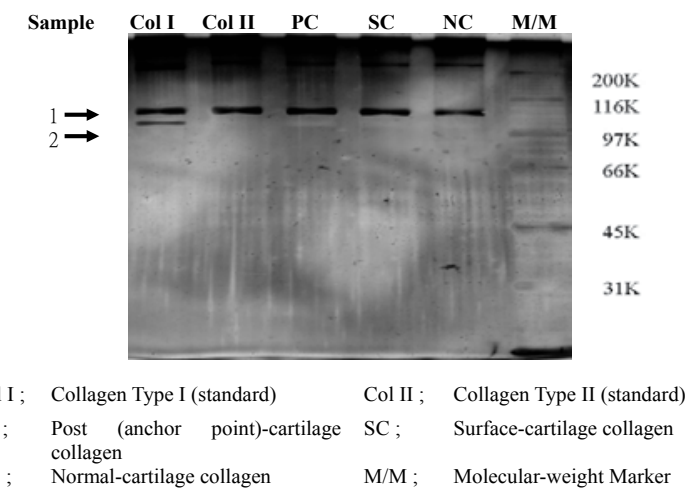

*PC: regenerated cartilage of the deep-hole area made by the drill. SC: regenerated cartilage of the surface area of $\mathrm{NC}$ : normal cartilage

Figure 13: SDS-PAGE of Collagen types I and II of regenerated cartilage 12 weeks after implantation. 
the surface of the regenerated cartilage (surface cartilage collagen; SC). The molecular weight of the regenerated cartilage was then compared with that of the collagen of normal cartilage using HPLC $[29,42]$. The graphs obtained using HPLC of NC, PC, and SC, respectively, are shown in Figure 15. In the collagen of normal cartilage, a peak is observed at 17 minutes and a shoulder is observed at 13 minutes. Peaks are also observed at 26 minutes and 28 minutes. The peak appearing at 13 minutes is a multimer of collagen molecules, and the peak occurring

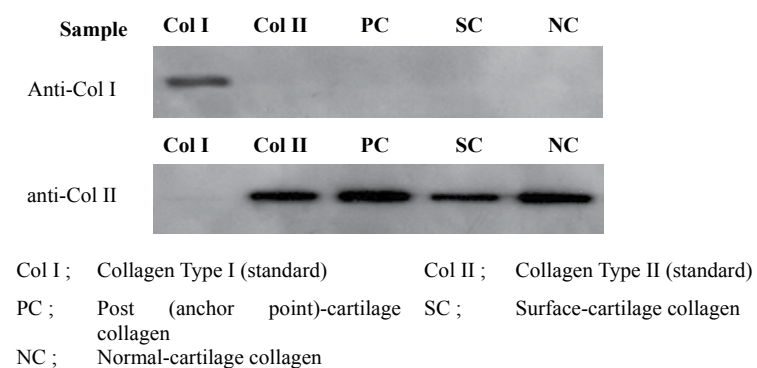

*PC: regenerated cartilage of the deep-hole area made by the drill. SC: regenerated cartilage of the surface area of NC: normal cartilage

Figure 14: Western blot analysis of Collagen types I and II about of regenerated cartilage 12 weeks after implantation by ECL KIT (Bio-rad)
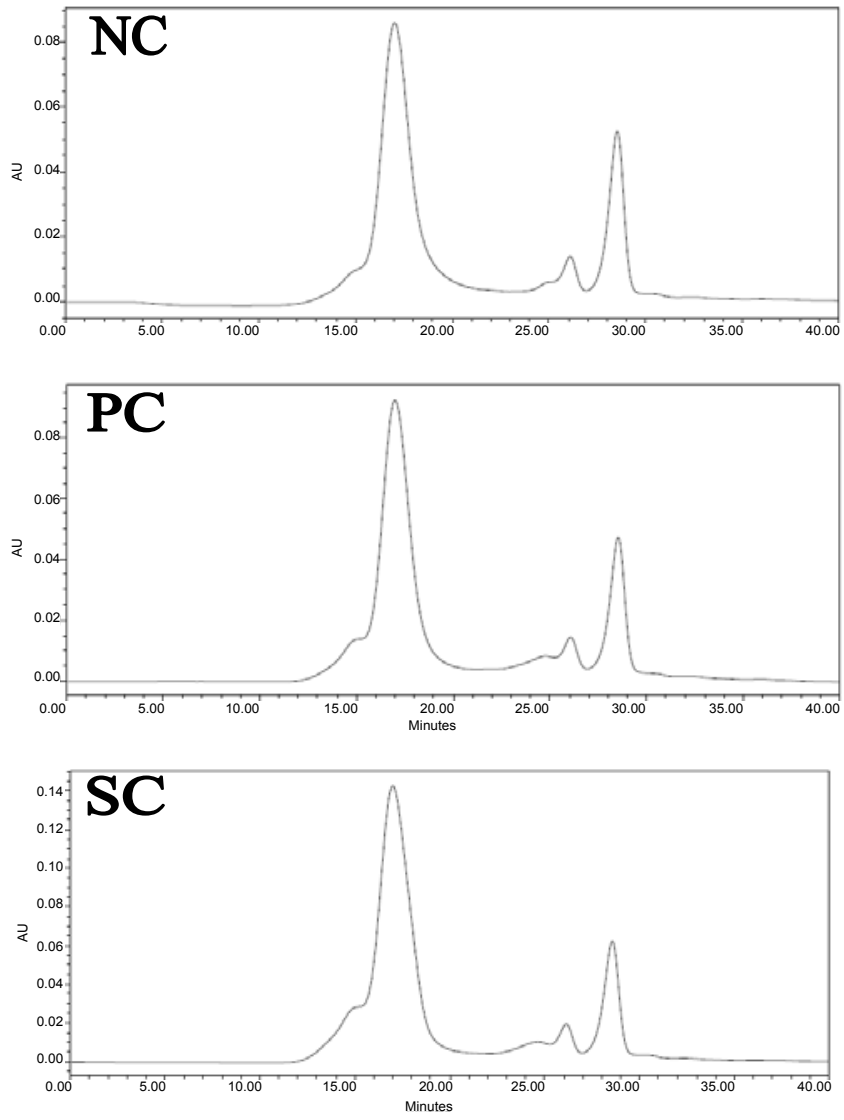

*PC: regenerated cartilage of the deep-hole area made by the drill. SC: regenerated cartilage of the surface area of NC: normal cartilage

Figure 15: HPLC Analysis of the regenerated cartilage and normal cartilage (U.V. absorbance detector Waters 2487 dual lamda, $220 \mathrm{~nm}$, flow solution $0.25 \mathrm{M} \mathrm{NaCl} / 5 \mathrm{mM}$ acetic acid, flow rate: $0.5 \mathrm{ml} / \mathrm{min}$ ). at 17 minutes represents collagen molecules. Moreover, the peaks observed at 26 minutes and 28 minutes represent telopeptide and pepsin, respectively, on the basis of their size of molecular weight. In the results of the HPLC analysis of PC and SC collagens isolated from newly formed cartilage, these collagens have the same molecular weights as those of the collagen of NC. In all samples, the main peak was observed at 17 minutes, the shoulder appeared at 13 minutes, the telopeptide peak was at 26 minutes, and the pepsin peak was at 28 minutes. On the basis of these results, we confirmed that collagen existing in normal cartilage and collagen formed from regenerated cartilage have the same molecular weight and with the results of pepsin digestion, these were degraded to atelocollagen separating telopeptide and becoming acidsoluble collagen. Collagen also existed as a monomer and multimer. Although molecular weight can be identified using HPLC analysis, identification of the collagen type is difficult. Therefore, the molecular weight of collagen was confirmed by SDA-PAGE and the collagen type was identified by western blot analysis.

\section{Discussion}

Tissue engineering which integrates and applies principles of cell biology, molecular biology, and material science, has been used to develop new techniques for recovering, improving, and maintaining the functions of injured tissue.

In tissue engineering, one of the most important areas is to develop a bio-matrix. This bio-matrix should maintain the three-dimensional structure, easily modulate the structure, possibly be applied to the surgical area and have both physical and chemical durability.

The biocompatibility of the scaffold must also be high and it should be appropriate to its biological environment. The scaffold must relate to the cell survival holding properties, such as cell viability, adherence, growth rate, etc., by interaction between the cells and the matrix and it must induce and maintain cell differentiation in order to regenerate a target tissue. It must also be efficient regarding its cost, convenience of use, etc. A general principle of tissue engineering using the bio-matrix is that biocompatible scaffolds with cultured cells inside, are implanted in order to gradually take the place of the polymeric structure.

The most well-known materials developed so far are: natural polymers such as fibrin, collagen, gelatin, and hyaluronic acid; synthetic polymers such as PLA, PGA, PLGA, and their copolymers; and inorganic materials such as TCP (tricalcium phosphate), calcium carbonate, and hydroxyapatite $[8,19,22,23,43-45]$. Based on these biomaterials, studies have been performed to regenerate various forms of tissue, such as nerve tissue and skin tissue, and studies regarding cartilage regeneration are now being actively performed [46-49].

Injured cartilage can hardly regenerate and so gradually undergoes fibrosis or fibrous cartilage formation which has substantially less effective physiological functions and so eventually causes severe arthralgia [50-52]. Various studies have attempted to implant autograft, allograft or macromolecular materials into the injured portion in order to repair a cartilage lesion [53-56]. In particular, autologous chondrocyte implantation (ACI) forms a hyaline-like cartilage which can be used to treat cartilage lesions $[37,57,58]$.

However, although the efficacy of ACI is definitely superior, it is not preferred because it presents difficulties in striping off periosteum and densely suturing periosteum to the surrounding tissue [34,35]. In addition, it has been reported that liquid-phase cells injected into a cavity formed by removing the injured cartilage and stitching up the periosteum, have sunken inward so as not to be uniformly distributed 
within the lesion [59]. To overcome these difficulties, many scientists have recently attempted to repair cartilage using tissue engineering which integrates cell therapy with bio-matrix technology $[34,42,60]$.

Studies regarding cartilage regeneration are now performed to regenerate injured cartilage using various biocompatible materials, i.e. natural materials such as alginate, agarose, polyglycolic acid, poly-Llactic acid, etc. as well as macromolecular synthetic materials [15,29].

Collagen and hyaluronic acid are also used as scaffolds for chondrocyte implantation, although it has been reported that their mechanical properties are not appropriate and that their biocompatibilities are low.

ACI using a collagen matrix is currently used as it contains a membrane on which chondrocytes are seeded and cultured for several days before it is cut to the correct size and shape of the defect.Regarding not using periosteum, collagen membrane methods can eliminate the need for a second incision for periosteal harvest as well as reducing the long surgery time and extensive suturing. However, there are also some potential problems with membranes using this method, such as the loss of critical chondrocytes because of the cutting and repeated manipulation of the seeded membrane. The possibility of detachment of the collagen membrane from the cartilage defect also cannot be ignored.

A natural substance, i.e., fibrin gel, is recently attracting attention as a good material for cartilage reconstruction. Fibrin has high biocompatibility and biodegradability, no toxicity, and has long been used as a clinical material for bleeding control. Fibrin is known for its use as an injectable carrier for generating regenerated cartilage $[33,35,38]$. The fibrin matrix also has high-quality cell adherence to three-dimensional scaffolds and grows actively and moves cells in the matrix in order to provide environmental conditions under which the tissue can be effectively regenerated by the cells. It has such a high biodegradability that cells in the matrix form new tissue to be completely substituted $[33,38,39]$.

In this study, cultured chondrocytes were mixed with fibrin and were injected into the injured portion of the cartilage, after which regenerated cartilage was histologically observed. From this observation, it could be confirmed that collagen type II was expressed as the most important quality of the cartilage and that it was directly connected with the normal tissue adjacent to the defect without any gap or intervening capsule. This is a very important part of cartilage function, especially lubricating by any absorbing impact and reducing friction on the articular surface. In this study, we verified that lacunae were formed by the cells so as to similarly construct the regenerated cartilage to the normal tissue. Also, through immunological and histochemical analysis and on electron microscopy images, we confirmed that newly formed cartilage has the same ultrastructure as normal tissue. On the other hand, the presence of many, large cellular processes and small lipid droplets both suggest that cartilage maturation was not completed at week 12 but was still continuing. This was also shown in the gene expression analysis results where we noted that col2al was expressed approximately twice as often as the normal tissue. This is also evidence that maturation of regenerated cartilage is still advancing at week 12 after the three-dimensional chondrocyte cure using fibrin has occurred.

On the other hand, the results of real-time RT-PCR using RNA separated from the tissue, showed the same expression pattern as normal tissue. Through reference and comparison to a non-inducible gene GAPDH, we were able to verify that coI2al, the gene of collagen type II, is a major transcript. Molecular weights of collagens were also separated from each tissue and were compared through HPLC in order to distinguish collagen type II shown at the early generation stage from collagen type II generated in the adult cartilage. We thus verified that collagen has the same molecular weight as normal tissue.

In gel-type ACI (GACI), the fibrin can maintain the shape of the articulation for approximately five minutes after injection, thus causing the cells to stay in the injected sites [61]. The hole in the middle of a cartilage defect performs an important function by increasing the adhesive force of the graft to the defect during knee motion. In surgical procedures, in order to prevent both the formation of fibro cartilaginous tissue [62] and detachment of the injected cell and fibrin mixture, bleeding control is very important. Fortunately, fibrin sealants are biological adhesives that mimic the final step of the coagulation cascade and thus help with the bone bleeding control [6].

This technique has some important surgical advantages. First of all, no sutures are required. Accordingly, the periosteal harvest procedure which requires another incision on the proximal tibia can be omitted. The large surgical incision size of conventional ACI is necessary mainly for suturingthe periosteum to the surrounding articular cartilage. However, using gel-type ACI, the surgical incision can be much smaller as it merely exposes the cartilage defect. As the surface of the injected cell gel mixture is very smooth after consolidation for approximately five minutes, early range of motion exercise is possible following surgery.

In all respects, gel-type ACI using fibrin may be the next generation of ACI for the repair of articular cartilage joint injury.

\section{Conclusion}

Gel-type ACI using fibrinfor articular cartilage defects of the knee, appears to be an effective method for the regeneration and growth of cartilage and also has many potential surgical advantages.

\section{Acknowledgement}

This study was partially supported by a grant of the Advanced Technology Center, Ministry of Knowledge Economy, Republic of Korea (10030360).

\section{References}

1. Hunter W (1995) Of the structure and disease of articulating cartilages. Clin Orthop Relat Res 3-6.

2. Bentley G, Minas T (2000) Treating joint damage in young people. BMJ 320 : 1585-1588.

3. Buckwalter JA (1998) Articular cartilage: injuries and potential for healing. Orthop Sports Phys Ther 28: 192-202.

4. Minas T, Nehrer S (1997) Current concepts in the treatment of articular cartilage defects. Orthopedics 20: $525-538$.

5. Chia SL, Gorna K, Gogolewski S, Alini M (2006) Biodegradable elastomeric polyurethane membranes as chondrocyte carriers for cartilage repair. Tissue Eng 12: 1945-1953.

6. Mawatari M, Higo T, Tsutsumi Y, Shigematsu M, Hotokebuchi T (2006) Effectiveness of autologous fibrin tissue adhesive in reducing postoperative blood loss during total hip arthroplasty: a prospective randomised study of 100 cases. J Orthop Surg (Hong Kong) 14: 117-121.

7. Grigolo B, Roseti L, Fiorini M, Fini M, Giavaresi G et al. (2001) Transplantation of chondrocytes seeded on a hyaluronan derivative (Hyaff-11) into cartilage defects in rabbits. Biomaterials 22: 2417-2424.

8. Cohen SB, Meirisch CM, Wilson HA, Diduch DR (2003) The use of absorbable co-polymer pads with alginate and cells for articular cartilage repair in rabbits. Biomaterials 24: 2653-2660.

9. Shortkroff S, Barone L, Hsu HP, Wrenn C, Gagne T, et al. (1996) Healing of chondral and osteochondral defects in a canine model: the role of cultured chondrocytes in regeneration of articular cartilage. Biomaterials 17: 147-154. 
Citation: Ko CK, Lee EY, Jang JD, Kim SJ, Suh DS, et al. (2012) Cartilage Regeneration Using a Fibrin and Autologous Cultured Chondrocytes Mixture in a Canine Model. J Tissue Sci Eng 3:114. doi:10.4172/2157-7552.1000114

10. Breinan HA, Minas T, Hsu HP, Nehrer S, Sledge CB, et al. (1997) Effect of cultured autologous chondrocytes on repair of chondral defects in a canine model. J Bone Joint Surg Am 79: 1439-1451.

11. Breinan HA, Minas T, Barone L, Tubo R, Hsu HP, et al. (1998) Histological evaluation of the course of healing of canine articular cartilage defects treated with cultured autologous chondrocytes. Tissue Eng 4: 101-113.

12. Lee CR, Grodzinsky AJ, Hsu HP, Spector M (2003) Effects of a cultured autologous chondrocyte-seeded type II collagen scaffold on the healing of a chondral defect in a canine model. J Orthop Res 21: 272-281.

13. O'Driscoll SW, Marx RG, Beaton DE, Miura Y, Gallay SH, et al. (2001) Validation of a simple histological, histochemical cartilage scoring system. Tissue Eng 7: 313-320

14. Buckwalter JA (1999) Evaluating methods of restoring cartilaginous articular surfaces. Clin Orthop Relat Res S224-S238.

15. van Susante JL, Buma $P$, Schuman L, Homminga GN, van den Berg WB et al. (1999) Resurfacing potential of heterologous chondrocytes suspended in fibrin glue in large full-thickness defects of femoral articular cartilage: an experimental study in the goat. Biomaterials 20: 1167-1175.

16. Roberts S, McCall IW, Darby AJ, Menage1 J, Evans H, et al. (2003) Autologous chondrocyte implantation for cartilage repair:monitoring its success by magnetic resonance imaging and histology. Arthritis Res Ther 5: R60-R73.

17. Moskalewski S, Hyc A, Osiecka-Iwan A (2002) Immune response by host after allogeneic chondrocyte transplant to the cartilage. Microsc Res Tech 58: 3-13.

18. Wang Q, Breinan HA, Hsu HP, Spector M (2000) Healing of defects in canine articular cartilage: distribution of nonvascular alpha-smooth muscle actincontaining cells. Wound Repair Regen 8: 145-158.

19. Wang X, Grogan SP, Rieser F, Winkelmann V, Maquet V, et al. (2004) Tissue engineering of biphasic cartilage constructs using various biodegradable scaffolds: an in vitro study. Biomaterials 25: $3681-3688$

20. Horky D, Tichy F (2002) Submicroscopic Structure of Equine Articular Cartilage. Acta Vet Brno 71: 151-157.

21. Modis L, Botos A, Kiviranta I, Lukacsko L, Helminen HJ (1996) Differences in submicroscopic structure of the extracellular matrix of canine femoral and tibia condylar articular cartilages as revealed by polarization microscopical analysis. Acta Biol Hung 47: 341-353.

22. Grad S, Kupcsik L, Gorna K, Gogolewski S, Alini M (2003) The use of biodegradable polyurethane scaffolds for cartilage tissue engineering: potentia and limitations. Biomaterials 24: 5163-5171.

23. Sechriest VF, Miao YJ, Niyibizi C, Westerhausen-Larson A, Matthew HW, et al. (2000) GAG-augmented polysaccharide hydrogel: A novel biocompatible and biodegradable material to support chondrogenesis. J Biomed Mater Res 49: $534-541$

24. Chubinskaya S, Huch K, Schulze M, Otten L, Aydelotte MB, et al. (2001) Gene Expression by Human Articular Chondrocytes Cultured in Alginate Beads. J Histochem Cytochem 49: 1211-1220.

25. Mok SS, Masuda K, Hauselmann HJ, Aydelotte MB, Thonar EJ (1994) Aggrecan synthesized by mature bovine chondrocytes suspended in alginate. Identification of two distinct metabolic matrix pools. J Biol Chem 269: 33021 33027

26. Roberts S, Menage J, Duance VC, Wotton S, Ayad S (1991) 1991 Volvo Award in basic sciences. Collagen types around the cells of the intervertebral disc and cartilage end plate: an immunolocalization study. Spine (Phila Pa 1976) 16: $1030-1038$

27. Roberts S, Caterson B, Evans EH, Eisenstein SM (1994) Proteoglycan components of the intervertebral disc and cartilage endplate: an immunolocalization study of animal and human tissues. Histochem J 26: 402411.

28. Oesser S, Seifert J (2003) Stimulation of type II collagen biosynthesis and secretion in bovine chondrocytes cultured with degraded collagen. Cell Tissue Res 311: 393-399.

29. Hendrickson DA, Nixon AJ, Erb HN, Lust G (1994) Phenotype and biological activity of neonatal equine chondrocytes cultured in a three-dimensional fibrin matrix. Am J Vet Res 55: 410-414.

30. Meachim G, Roberts C (1971) Repair of the joint surface from subarticular tissue in the rabbit knee. J Anat 109: 317-327.
31. Engkvist O, Johansson SH (1980) Perichondrial arthroplasty: a clinical study in twenty-six patients. Scand J Plast Reconstr Surg 14: 71-87.

32. Fuller JA, Ghadially FN (1972) Ultrastructural observations on surgically produced partial-thickness defects in articular cartilage. Clin Orthop Relat Res 86: 193-205

33. Homminga GN, Buma P, Koot HW, van der Kraan PM, van den Berg WB (1993) Chondrocyte behavior in fibrin glue in vitro. Acta Orthop Scand 64: 441-445

34. Risbud MV, Sittinger M (2002) Tissue engineering: advances in in vitro cartilage generation. Trends Biotechnol 20: 351-356.

35. Keller J, Andreassen TT, Joyce F, Knudsen VE, Jorgensen PH, et al. (1985) Fixation of osteochondral fractures. Fibrin sealant tested in dogs. Acta Orthop Scand 56: 323-326.

36. Ghadially FN, Thomas I, Oryschak AF, Lalonde JM (1977) Long term results of superficial defects in articular cartilage: A scanning electron-microscope study. J Pathol 121: 213-217

37. Brittberg M, Lindahl A, Nilsson A, Ohlsson C, Isaksson O, et al. (1994) Treatment of deep cartilage defects in the knee with autologous chondrocyte transplantation. N Engl J Med 331: 889-895.

38. Silverman RP, Bonasser L, Passaretti D, Randolph MA, Yaremchuk MJ (2000) Adhesion of Tissue-Engineered Cartilage to Native Cartilage. Plast Reconst Surg 105: 1393-1398.

39. Ronga M, Grassi FA, Bulgheroni P (2004) Arthroscopic Autologous Chondrocyte Implantation for the Treatment of a Chondral Defect in the Tibial Plateau of the Knee. Arthroscopy 20: 79-84

40. Peterson L, Brittberg M, Kiviranta I, Akerlund EL, Lindahl A (2002) Autologous chondrocyte transplantation: Biomechanics and long-term durability. Am J Sports Med 30: 2-12

41. Marcacci M, Zaffagnini S, Kon E, Visani A, lacono F, et al. (2002) Atrhroscopic autologous chondrocyte transplantation: technical note. Knee Surg Sports Traumatol Arthrosc 10: 154-159.

42. Koch RJ, Gorti GK (2002) Tissue engineering with chondrocytes. Facial Plas Surg 18: 59-68.

43. Frenkel SR, Toolan B, Menche D, Pitman MI, Pachence JM (1997) Chondrocyte transplantation using a collagen bilayer matrix for cartilage repair. J Bone Join Surg $\mathrm{Br}$ 79: 831-836.

44. Grigolo B, Lisignoli G, Piacentini A, Fiorini M, Gobbi P, et al. (2002) Evidence for redifferentiation of human chondrocytes grown on a hyaluronan-based biomaterial (HYAFF 11): molecular, immunohistochemical and ultrastructural analysis. Biomaterials 23: 1187-1195

45. Nehrer S, Breinan HA, Ramappa A, Shortkroff S, Young G, et al. (1997) Canine Chondrocytes seeded in type I and type II collagen implants investigated in vitro. J Biomed Mater Res 38: 95-104

46. Yamada Y, Boo JS, Ozawa R, Nagasaka T, Okazaki Y, et al. (2003) Bone regeneration following injection of mesenchymal stem cells and fibrin glue with a biodegradable scaffold. J Craniomaxillofac Surg 31: 27-33.

47. Botchwey EA, Dupree MA, Pollack SR, Levine EM, Laurencin CT (2003) Tissue engineered bone: Measurement of nutrient transport in three-dimensional matrices. J Biomed Mater Res 67: 357 -367.

48. Unger RE, Krump-Konvalinkova V, Peters K, Kirkpatrick CJ (2002) In vitro expression of the endothelial phenotype: Comparative study of primary isolated cells and cell lines, including the novel cell line, HPMEC-ST1.6R. Microvasc Res 64: 384-397.

49. Unger RE, Peters K, Wolf M, Motta A, Migliaresi C, et al. (2004) Endothelialization of a non-woven silk fibroin net for use in tissue engineering: growth and gene regulation of human endothelial cells. Biomaterials 25: 5137-5146.

50. Pridie K (1959) A method of resurfacing osteoarthritic knee joints. J Bone Join Surg $\mathrm{Br} 41: 618$

51. Johnson LL (1986) Arthroscopic abrasion arthroplasty historical and pathologic perspective: Present status. Arthroscopy 2: 54-69.

52. Bobic V, Noble J (2000) Articular cartilage: To repair or not to repair. J Bone Joint Surg Br 82: 165-166.

53. Jackson DW, Scheer MJ, Simon TM (2001) Cartilage substitutes: overview of basic science and treatment options. J Am Acad Orthop Surg 9: 37-52. 
Citation: Ko CK, Lee EY, Jang JD, Kim SJ, Suh DS, et al. (2012) Cartilage Regeneration Using a Fibrin and Autologous Cultured Chondrocytes Mixture in a Canine Model. J Tissue Sci Eng 3:114. doi:10.4172/2157-7552.1000114

54. Mitchell N, Shepard N (1976) The resurfacing of adult rabbit articular cartilage by multiple perforations through the subchondral bone. J Bone Joint Surg Am 58: $230-233$

55. Ritsila VA, Santavirta S, Alhopuro S, Poussa M, Jaroma H, et al. (1994) Periosteal and perichondral grafting in reconstructive surgery. Clin Orthop Relat Res 302: 259-265.

56. Amiel D, Coutts RD, Abel M, Stewart W, Harwood F, et al. (1985) Rib perichondrial grafts for the repair of full-thickness articular-cartilage defects. A morphological and biochemical study in rabbits. J Bone Joint Surg Am 67: 911-920.

57. Peterson L, Minas T, Brittberg M, Nilsson A, Sjögren-Jansson E, et al. (2000) Two- to 9-years after autologous chondrocyte transplantation of the knee. Clin Orthop Relat Res 374: 212-234.

58. Minas T (1998) Autologous cultured chondrocyte implantation in the repair of focal chondral lesions of the knee: Clinical indications and operative technique. J Sports Traumatol Rel Res 20: 90-102.

59. Sohn DH, Lottman LM, Lum LY, Kim SG, Pedowitz RA, et al. (2002) Effect of gravity on localization of chondrocytes implanted in cartilage defects. Clin Orthop Rel Res 394: 254-262.

60. Goessler UR, Horman K, Ridel F (2004) Tissue engineering with chondrocytes and function of the extracellular matrix (Review). Int J Mol Med 13: 505-513.

61. Ho W, Tawil B, Dunn JC, Wu BM (2006) The behavior of human mesenchymal stem cells in 3D fibrin clots: Dependence on fibrinogen concentration and clot structure. Tissue Eng 12: 1587-1595.

62. Horas U, Pelinkovic D, Herr G, Aigner T, Schnettler R (2003) Autologous chondrocyte implantation and osteochondral cylinder transplantation in cartilage repair of the knee joint. A prospective, comparative trial. J Bone Join Surg Am 85: 185-192. 